\title{
Responsibility Of Travel Agent For Losses Suffered By Consumers Of Its Services Users
}

\author{
I Ketut Setia Budi; Desak Komang Devi Karina Evansa; I Ketut Widia; I Wayan Rideng, \\ Magister of Law, Postgraduate Program, Warmadewa University Denpasar, Bali
}

\begin{abstract}
Travel Agent often held various forms of tour packages to attract tourists who will come to a tourist area. These packages include hotel accommodation services, restaurant, and various other forms of tourism businesses. However, the existence of tour packages offered by this Travel Agent is often not supported by a factor of tourist safety protection, which is clear. This study aims to find out the responsibility of a travel agent for consumers of service users who suffer losses in service and to find out the procedure to get compensation for service users if they suffer losses. The research method used is normative research method, which is this research carried out by examining library material or primary legal material and secondary legal material. The results of the study show that the responsibility of travel agent for consumers of service users who suffer losses in service is by paying attention to the principles of legal protection for consumers, which is the obligation of business operators to replace the losses suffered by consumers whose in this case are tourists. The procedure to obtain compensation for services users if they suffered losses through several stages, those are the first stage that is the heirs of the victims of the accident contact the police to then apply for compensation. The second stage is the victim and the heirs of the victim fill out a letter of compensation for the accident provided free of charge by P.T. Jasa Raharja (Persero). To get compensation, the victim or the heirs of the victim must fulfil the requirements requested by P.T. Jasa Raharja (Persero).
\end{abstract}

Keywords: Responsibility, Travel Agent, Losses, Service Users

\section{Introduction}

In its aim to plan tourist travel activities, the Travel Agent often organizes various forms of tour packages to attract tourists who will come to a tourist area. These packages include hotel accommodation services, restaurant, and various other forms of tourism businesses. However, the existence of tour packages offered by this Travel Agent is often not supported by tourist safety protection factors, which is clear. It is very rare to see special agreements made in writing between the Tourist Travel Agent and Tourists regarding the safety of the tourists themselves. That in Article 26 point d of Law Number 10 of 2009 concerning Tourism, it has been clearly stated that Tourism Entrepreneurs are obliged to provide comfort, hospitality, security protection, and tourist safety. That in Article 11 point 1 Letter a in the Regional Regulation of Bali Province, only states that Travel Agent Services Business states 
Entrepreneurs are obliged to provide protection to tourists, in the form of guarantees of safety and security as long as these tourists are in Bali. Legal protection for users of tourism services both domestic and foreign and tourism entrepreneurs is very necessary because in international law it has been stated that the State is obliged to protect its citizens and foreigners in their countries. Meanwhile, when viewed in the economic aspect, the guarantee of legal protection will greatly influence the market response in the tourism industry. Cooperation agreements between tourism services business entities and service users should be made in the form of details and more clearly. This is very important so that what is the achievement can be fulfilled in an effort to achieve the objectives of the agreement made by the parties. If the agreement that functions as a guideline in the implementation of cooperation does not pay attention to the legal requirements and elements that should be in the agreement, then this will be very influential in the implementation of the agreement.

On the other hand, service users also have an interest in getting the best service from the Travel Agent company. The existence of these interests should be a meeting point in establishing a cooperative relationship that is mutually beneficial and balanced between the two parties. The cooperative relationship is contained in a more specific agreement. This specific agreement takes the form of a cooperation agreement and covers its implementation, intended so that both parties can implement their respective rights and obligations without being harmed. But in reality, many consumers are harmed by the actions of the Travel Agent and consumers rarely take legal action to defend their rights. The consumers give up in more and allow when there is unilateral action from the Tourist Travel Agent because of an exoneration clause (freeing someone or business entity from a demand or responsibility) in the agreement. This is because consumers consider it to be part of an agreement that must be obeyed and often not realized by consumers when signing the agreement even if realized but because consumers need the tour package, then inevitably the consumer must agree to the conditions that have been made in advance by Tourist Travel Agent unilaterally or jointly. Besides that, there are often 2 (two) different agreements between the Tourist Travel Agent and the committee and the leadership of the institution. Related to the responsibility of a travel agent for consumers of service users who suffer losses in service, some studies have been conducted, such as [2] which studies about the forms of legal protection for consumers who used travel agency services according to Consumer Protection Act (Undang-Undang Pelindungan Konsumen)1999. The legal protection for travel agency service users has been regulated in Consumer Protection Act (Undang-Undang Pelindungan Konsumen), if a dispute occurs between consumers who use a travel agency service with business actor, it can be resolved through non-litigation settlement and litigation settlement. Travel agents are responsible for the products they offer to consumers. If there are things that are detrimental to consumers due to an activity related to the product that is distributed to consumers, then the business actor is responsible for compensating for the loss even though the responsibility is only limited to responsibilities in accordance with the profession (Strict Professional Liability), namely responsibility in accordance with agreements that have been agreed with consumers due to negligence of business actor have caused losses to consumers. Furthermore, [3] also conducted the similar study, which is focusing on the form of agreement agreed between the travel agency CV. Arlinta with users and travel agency liability in case of loss suffered by the users. The results of this study showed that the form of agreement used by CV. Arlinta with users is oral or unwritten agreements and liability CV. Arlinta if there is a loss to the users, the CV. Arlinta is willing to compensate if it is proven guilty. Every problem in CV. Arlinta will be settled by negotiating. [4] in her study discussed about legal relationship between travel agency services company PT Arie Tours and its customers, and the 
responsibility of travel agency services company PT Arie Tours to consumers who suffer losses. The results of this study reveal that the legal relationship between travel company PT Arie Tour and the consumers of PT Arie Tours travel service is a relationship to do work in the form of travel services. The legal relationship came from an agreement between the travel service company PT Arie Tour and its consumers, which creates a bond in the form of rights and obligations. The responsibility of travel company PT Arie Tours for consumers who suffered losses due to default by the travel service company PT Arie Tours is a form of responsibility in the form of compensation. The compensation includes returning money equivalent to the loss suffered by consumers, replacing similar services or equivalent value, and providing compensation to consumers who are disadvantaged as a form of apology from travel company PT Arie Tours. Based on the background and the relevant studies above, thus, this study aims to find out the responsibility of a travel agent for consumers of service users who suffer losses in service and to find out the procedure to obtain compensation for consumers of service users who suffered losses.

\section{Methods}

The type of research used in this study is normative legal research. Normative Legal Research is research conducted by examining library material or primary legal material and secondary legal material. Normative research is conducted because of the obscurity of the norms of Republic of Indonesia Government Regulation Number 67 of 1996 concerning the Implementation of Tourism with Law Number 8 of 1999 concerning Consumer Protection, which in Part Two Article 7 of Act Number 8 of 1999 only regulates the provision of compensation, compensation and/or replacement if the goods and/or services received or utilized are not in accordance with the agreement, without specifying how the procedure must be taken by the consumer to request the compensation, whereas to obtain such compensation or loss, the consumer is required to undergo a compensation application procedure.

\section{Results And Discussion}

Based on the results of the analysis conducted, thus the results discussion of this study is described as following:

\subsection{Responsibility of Travel Agent for Consumers of Service Users Who Have Losses in Service}

Based on the Government Regulation of the Republic of Indonesia Number 67 of 1996 concerning Implementation of Tourism Paragraph 1 Article 10 concerning Travel Agent Services Business states that:

1. The travel agent must:

a. Fulfil the type and quality of components of tour packages that are packaged and/or promised in tour packages.

b. Providing optimal service for tourists who orders, arranges documents and carry out trips through a travel agent

2. The travel agent is responsible for the safety of tourists travelling on tours based on the tour packages it sells. 
If a violation occurs due to negligence committed by the tour and travel agent, then the travel agent's business permit may be revoked by the local Regent/Mayor with considerations taken.

1. Business license can be revoked if:

a. Not fulfilling the stipulated requirements for the business of travel agent and tour travel agent.

b. Not doing business activities for 2 consecutive years.

c. Conduct activities that conflict with applicable regulations/provisions.

d. Not fulfilling the obligation to submit a business activity report to the Regent/Mayor.

e. It was found convincing things from the results of the local inspection to carry out sanctions in accordance with the applicable provisions

2. Revocation of business licenses can be done after first being given 3 consecutively written warnings within 90 working days.

3. In addition to sanctions for revocation of business, the recipient/holder of a business permit for a travel agent and a travel agent may also be subject to other sanctions in accordance with the applicable laws and regulations.

Talking about the responsibilities of a business travel agent can not be separated from who is responsible for actions to whom the deed can be covered and whether each person who commits an act where the consequences of his actions can cause harm to the person, can be justified by the maker.

In violating the law or the responsibility of legislation, it means that the responsibility is borne by the person who commits an act that violates the law which the result of his actions is what creates a responsibility which the responsibility must be borne by itself. Both the consequences of his actions lead to the existence of a responsibility which the responsibility must be borne by him alone. Both of the actions that violate the law are desired or not desired by the maker or in the sense because they are not careful or negligence causes harm to others. Likewise, the responsibility of a producer for the goods produced. Producers are responsible for the goods they produce that are circulating in the market and reach the consumers as those who use or use product goods from producers.

Consumer protection in Indonesia can be said to have become a social system that cannot be separated from various things, especially seen from the point of economic law. As one of the economic objects, consumer problems do not escape the problems of rights and interests, which need attention, especially in relation to aspects of the management of goods and services. By paying attention to the principles of legal protection for consumers, it is the obligation of business operators to replace losses suffered by consumers who in this case are tourists.

\subsection{Procedures to Obtain Compensation for Consumers who Suffered Losses}

Service users are anyone who uses goods and/or public transportation services to fulfil their own and other people's interests. Viewed from its position in the agreement to transport people, passengers are people who tie themselves to pay for transportation costs [7].

In this perspective, the position of service users is as consumers, because service users are the legal subjects of service users, who are intended for themselves, which users of these services are not traded again. Service users in their position as consumers have rights formulated in Article 4 of Consumer Protection Laws are:

a. The right to comfort, and safety in consuming goods and/or services;

b. The right to choose and to get goods and/or services in accordance with the exchange rate and conditions and guarantees promised; 
c. Right to information that is correct, clear and honest regarding the condition and guarantee of goods and/or services;

d. The right to be heard opinions and complaints about the goods and/or services used;

e. The right to get advocacy, protection, and efforts to properly resolve consumer protection disputes;

f. The right to get guidance and education for consumers;

g. The right to be treated or served correctly and honestly and not discriminatory;

h. The right to receive compensation, and/or substitution, if the goods and/or services received are not in accordance with the agreement or not as appropriate;

i. Rights stipulated in other statutory provisions.

Consumer rights as mentioned in Article 4 of Consumer Protection Laws are broader than the basic rights of consumers as first stated by President of the United States J.F Kennedy at the congress on March 15, 1962, which consists of:
a. The right to obtain security;
b. The right to vote;
c. The right to get information;
d. The right to be heard [8].

In connection with the occurrence of accidents of users of road services and traffic, the victims or the heirs of accident victims of service users and travel agent, submit claims for compensation to P.T. Jasa Raharja (Persero) Representative of Bali in accordance with procedures stipulated by Law Number 33 of 1964 and Law Number 34 of 1964 in conjunction with Government Regulation Number 17 of 1965 and Government Regulation Number 18 of 1965.

The procedures for filing claims for compensation for accident victims of service users and travel agent are as follows:

1) First Stage

The heirs or victims of accidents contact the Police office, in this case, the local Police Traffic Unit, which then goes to the One Roof Single Administration office or the nearest of P.T. Jasa Raharja (Persero), to then submit a compensation request. The heirs or victims fill out compensation forms from P.T. Jasa Raharja (Persero) that has been provided. In the submission form there are two parts, they are:

a. The first part is filled by heirs or accident victims regarding the name, relationship with the victim, address, occupation, gender, status, nature of the injury.

b. The second part, the form is filled in by P.T. Jasa Raharja (Persero), which is in the OneStop Single Administration System, contains cases of accidents, the identity of the vehicle involved, the identity and nature of the victim's injury, and accident conclusions about the scope of the guarantee.

2) Second Stage

Based on information obtained by Jasa Raharja from the victims and their heirs and after Jasa Raharja provided an explanation of the procedure for requesting compensation for the accident to the victim. The next step is the victim and the heirs of the victim fill out the compensation letter that is provided free of charge by P.T. Jasa Raharja (Persero), by attaching:

a) Information on traffic accidents signed by Jasa Raharja officers in the form of police reports and sketches of the accidents that occurred, both for victims of motor vehicle accidents, telegrams or news of accidents from P.T. Kereta Api (Persero). News of accidents from the 
captain/martyrdom officer and/or other authorized officials to crash ships/rivers/lakes and crossings and aircraft.

b) Health information from doctors, Community Health Centers or hospitals, the place of victims are treated or undergoing treatment. This health information contains injuries that outline contains an explanation of the identity of the treating physician, an explanation of injury, or injuries suffered by the victim, diagnosis of the condition and relief measures that have been or will be carried out against the victim.

In the case that the victim dies, the information attached is a death certificate from the doctor of the hospital where the victim was treated. Specifically, regarding this matter, other necessary equipment is the statement of heirs. This information must be filled in and signed by the local Village Head or the authorized official who explains: the identity of the victim and the heir of the victim.

To get compensation, the victim or the heirs of the victim must fulfil the requirements requested by P.T. Jasa Raharja (Persero). For completeness, proof documents must be submitted as follows:

a) In the case of death:

1) The verbal process of traffic police or other authorities regarding accidents that have occurred with the transportation equipment concerned, which resulted in the death of the heir.

2) The decision of a judge or other authorized party regarding inheritance concerned.

3) Doctor's certificates and other evidence deemed necessary for the ratification of the facts of death that occurred, the cause of death relationship with the use of transportation equipment and things that determine the amount of payment of funds that must be given.

b) In permanent disability or injury

1) The verbal process of traffic police or other authorized persons regarding accidents that have occurred with the transportation equipment concerned, which results in permanent disability/injury to the claimant.

2) A doctor's certificate of the type of permanent/injury defect that has occurred as a result of an accident of service users and travel agent.

3) Other proof documents deemed necessary for the ratification of the fact of permanent disability/injury with the use of transportation equipment, and matters that determine the amount of payment of funds that must be given.

To get a guarantee of accident insurance for service users and accident of travel agent, in addition to the information above, other evidence that must be attached such as:

1) Police report along with a plan for a crime scene or a report of the authorities;

2) Receipt of genuine and legal treatment and medical expenses if the victim is injured;

3) Identity Card or other valid identities;

4) Birth Certificate or Certificate of Birth known;

5) Marriage Certificate;

6) Family Card;

7) Description of permanent/injured disability from a doctor.

In a travel agent accident, anyone who is outside the travel agent's transportation that controls the victim will be given the right to payment of the travel agent's accident fund. Fund payments are given in the following cases:

1) The victim dies, within 365 days, after the occurrence of the related accident;

2) The victim gets a permanent disability, within 365 days after the occurrence of the related accident; 
3) The costs of medical care and treatment that are issued from the first day after an accident, for a maximum of 365 days;

4) The death victim does not have an heir, to the party who organizes his burial, is given compensation for burial fees.

\section{Conclusions}

Based on the findings in the study over the execution of the guarantee of land-bound Dependent Rights online, then it can be concluded that 1) the responsibility of a travel agent for consumers of service users who suffered losses in service should pay attention to the principles of legal protection toward consumers. This responsibility includes responsibility for the safety of service users. This is done by insuring service users in accordance with the agreement. In addition, the responsibility of the Travel Agent also covers the safety of property carried by service users. If the luggage is lost or damaged, the service user has the right to get compensation. 2) procedure for obtaining compensation for service users if they suffered losses through several stages, they are the first stage; the heirs of the victims of the accident contact the police to then submit a compensation request. The second stage is the victim and the heirs of the victim fill out a letter of compensation for the accident provided free of charge by P.T. Jasa Raharja (Persero). To get compensation, the victim or the heirs of the victim must fulfil the requirements requested by P.T. Jasa Raharja (Persero).

\section{References}

[1] "Law Number 10 of 2009 concerning Tourism,".

[2] S. Nurhayati, "Perlindungan Hukum Bagi Konsumen Pengguna Jasa Biro Perjalanan Menurut Undang-Undang Nomor 8 Tahun 1999 Tentang Perlindungan Konsumen,” vol. 2, no. 2, 2009.

[3] R. Al Salam, "Tanggung Jawab Biro Travel Perjalanan Wisata Terhadap Penumpang Pengguna Jasa Travel (Studi Kasus cv. Arlinta Surabaya)," Universitas Pembangunan Nasional Veteran Jawa Timur, 2013.

[4] L. E. Putri, "Tanggung Jawab Perusahaan Jasa Perjalanan (Travel Agency) Terhadap Konsumennya (Studi Pada PT Arie Tours dan Travel Cabang Bandar Lampung),” pp. 1-14, 2017.

[5] "Republic of Indonesia Government Regulation Number 67 of 1996 concerning the Implementation of Tourism," .

[6] "Law Number 8 of 1999 concerning Consumer Protection,".

[7] M. Abdulkadir, Hukum Pengangkutan Niaga, V. Bandung: PT. Citra Aditya Bakti, 2013.

[8] N. V. voor Rechtsvergelijking, Geschriften van de Nederlandse Vereniging voor Rechtsvergelijking. Deventer Kluwer, 1968. 